\title{
Yearbook of Morphology
}

\author{
Editors: Geert Booij \\ Jaap van Marle \\ Consulting Editors: Stephen Anderson (Yale) \\ Mark Aronoff (Stony Brook, N.Y.) \\ Laurie Bauer (Wellington) \\ Mark Baker (Montreal) \\ Rudie Botha (Stellenbosch) \\ Joan Bybee (Albuquerque, N.M.) \\ Andrew Carstairs-McCarthy (Christchurch) \\ Wolfgang Dressler (Wien) \\ Jack Hoeksema (Groningen) \\ Rochelle Lieber (Durham, N.H.) \\ Peter Matthews (Cambridge, U.K.) \\ Franz Rainer (Wien) \\ Sergio Scalise (Bologna) \\ Henk Schultink (Utrecht) \\ Arnold Zwicky (Columbus, Ohio/Stanford)
}

Editorial address: Editors, Yearbook of Morphology

Vakgroep Taalkunde, Vrije Universiteit

De Boelelaan 1105

1081 HV Amsterdam, The Netherlands

e-mail: booij@aap.let.vu.nl 


\title{
YEARBOOK OF MORPHOLOGY 1995
}

\author{
Edited by \\ GEERT BOOIJ \\ General Linguistics, \\ Free University, \\ Amsterdam, The Netherlands \\ and \\ JAAP VAN MARLE \\ Director, \\ P.J. Meertens Institute, \\ Amsterdam, The Netherlands
}

KLUWER ACADEMIC PUBLISHERS

DORDRECHT / BOSTON / LONDON 
Published by Kluwer Academic Publishers, P.O. Box 17, 3300 AA Dordrecht, The Netherlands.

Kluwer Academic Publishers incorporates the publishing programmes of D. Reidel, Martinus Nijhoff, Dr W. Junk and MTP Press.

Sold and distributed in the U.S.A. and Canada by Kluwer Academic Publishers,

101 Philip Drive, Norwell, MA 02061, U.S.A.

In all other countries, sold and distributed by Kluwer Academic Publishers Group, P.O. Box 322, 3300 AH Dordrecht, The Netherlands.

Printed on acid-free paper

All Rights Reserved

(C) 1996 Kluwer Academic Publishers

No part of the material protected by this copyright notice may be reproduced or utilized in any form or by any means, electronic or mechanical, including photocopying, recording or by any information storage and retrieval system, without written permission from the copyright owner.

Printed in the Netherlands 


\section{Table of Contents}

\section{Theme: Inflection and Derivation}

A selection of papers from the 6th International Morphology Meeting, Szombathely, 16-18 September, 1994, organized by the Research Institute for Linguistics of the Hungarian Academy of Sciences

\section{Guest editor: Ferenc Kiefer}

GEERT BOOIJ / Inherent versus contextual inflection and the split morphology hypothesis

RAY FABRI / The inverse morphology of Plains Cree (Algonquian)

MARTIN HASPELMATH / Word-class-changing inflection and morphological theory

JAAP VAN MARLE / The unity of morphology: on the interwovenness

of the derivational and inflectional dimension of the word

FRANZ RAINER / Inflection inside derivation: evidence from

Spanish and Portuguese

DIETER WUNDERLICH / Minimalist morphology: the role of paradigms

\section{Other Articles}

HARALD CLAHSEN, GARY MARCUS, SUSANNE BARTKE and RICHARD WIESE / Compounding and inflection in German child language

CHRIS GOLSTON and RICHARD WIESE / Zero morphology and constraint interaction: subtraction and epenthesis in German dialects

ROBERT D. HOBERMAN / Subtractive morphology and morpheme identity in Arabic pausal forms

\section{Short Notice}

CAROL CHAPMAN / Perceptual salience and affix order:

noun plurals as input to word formation

\section{Book Notices}

GEERT BOOIJ / Ferenc Kiefer (ed.), Papers from the 4th International Morphology Meeting; Joel Nevis et al. (eds.), Clitics, a Comprehensive Bibliography; Livia Tonelli \& Wolfgang U. Dressler (ed.), Natural Morphology, Perspectives for the Nineties

FRANZ RAINER / Maria Grossmann, Opposizioni direzionali e prefissazione 


\title{
Inherent versus contextual inflection and the split morphology hypothesis
}

\author{
GEERT BOOIJ
}

\section{INTRODUCTION ${ }^{1}$}

The position of morphology in the grammar is the subject of a lively debate. ${ }^{2} \mathrm{~A}$ major issue is that of the demarcation between morphology and syntax. Are there word formation processes that can be or should be accounted for by independently motivated syntactic rules, or is all word formation to be accounted for by a separate morphological component? A second important issue is that of the relation between word formation and inflection. Word formation seems to be more of a lexical nature, whereas inflection has a syntactic flavour. So the question is whether inflection should be seen as part of the pre-syntactic morphological component, or as belonging to a separate post-syntactic component of inflection, in which the morphosyntactic features of words are spelled out.

In this paper I will focus on the second issue, that of the relation between word formation (including compounding and derivation) and inflection.

The distinction between inflection and derivation has been questioned by quite a number of morphologists. For instance, the Dutch morphologist Schultink added the following thesis to his 1962 dissertation:

The distinction which grammars of Dutch make between conjugation and declination on the one hand, and derivation on the other, is not supported by the factual language data. [my translation, GEB]

This is a pretty strong claim, and it comes as no surprise that other linguists opposed it. For instance, the well known Dutch structuralist linguist A.W. de Groot argued against this thesis (De Groot 1966). His main arguments are that inflection is always peripheral to derivation (a structural argument), and that, unlike inflection, derivation is semantically often irregular.

A radical interpretation of the distinction between derivation and inflection can be found in more recent morphological literature. This radical proposal is to split morphology into two different components. In particular, Perlmutter (1988) argued that morphology be split into two separate components of the grammar: derivation is pre-syntactic, and inflection is post-syntactic. The same position is taken by Anderson (1992).

It should be pointed out here that one should not identify the position that a distinction between derivation and inflection is necessary, and the split morphology hypothesis. There is another position, one which I would like to defend here, which 
is that, although a distinction between derivation and inflection is necessary, they should be kept together in one morphological component. In other words, I am going to argue against the split morphology hypothesis, but will present arguments that the inflection - derivation distinction should be maintained.

The specific topic of this paper is the distinction between inherent and contextual inflection, and its relevance for the split morphology issue. In section 2 I will deal in more detail with this distinction, which was also defended in Booij (1994). Subsequently, in Section 3 I will discuss how far this distinction will help us to account for the constraints on the interaction between inflection and word formation. My results and conclusions will be summarized in Section 4 .

\section{INHERENT INFLECTION}

As proposed in Booij (1994), two types of inflection should be distinguished, inherent and contextual inflection. Inherent inflection is the kind of inflection that is not required by the syntactic context, although it may have syntactic relevance. Examples are the category number for nouns, comparative and superlative degree of the adjective, and tense and aspect for verbs. Other examples of inherent verbal inflection are infinitives and participles. Contextual inflection, on the other hand, is that kind of inflection that is dictated by syntax, such as person and number markers on verbs that agree with subjects and/or objects, agreement markers for adjectives, and structural case markers on nouns. We should realize, however, that there is no clearcut boundary between structural and semantic case (Booij 1994).

Note that 'syntactic relevance' does not suffice as a criterion for demarcating inflection from derivation, since derivation also has syntactic implications in that it may change the syntactic (sub)category of a word, and its syntactic valency.

This distinction between inherent and contextual inflection is sometimes reflected by traditional grammars. For instance, in Hungarian morphology there is a separate term for endings such as the plural, the conditional suffix, and the imperative suffix, which are considered to be more derivational (Kiefer, pers. comm.). To give another example, in the grammar of Georgian the term 'screeve' is used for a verb form marked for every feature except person and number. "All verb forms within a given screeve will have the same aspect, tense, mood, transitivity, etc., differing only in terms of [...] person and number affixes" (Imidadze \& Tuite 1992: 47). Thus, the notion 'screeve' presupposes a distinction between inherent and contextual inflection. Kuryłowicz (1964: 17) also made this distinction when he discussed the difference between plural number and case:

"If the two inflexional forms differ semantically only, like Latin urbs (singular): urbes (plural), the status of such a pair will be intermediate between the relation basic word:derivative and the relation urbs:urbem. [...]

Therefore: 
urbs: urbanus $=$ two different words

urbs: urbes = one word, with forms semantically different and having secondary syntactical functions,

urbs:urbem = one word, with forms semantically identical, syntactically different" (Kuryłowicz 1964: 17)

In the following subsections I will present data that reflect the inherent / contextual distinction. Inherent inflection is more similar to derivation, and it may feed word formation, unlike contextual inflection, which is peripheral to inherent inflection. Language acquisition and language change also appear to reflect this distinction. I will use mainly data from Dutch.

\subsection{Similarities between inherent inflection and derivation}

Like many derivational morphological categories, plural nouns in Dutch (a case of inherent inflection) have the following properties:

a. for many singular nouns, there is no plural counterpart, just as many words do not have a derivative in every possible category;

b. like many derived words, the plural noun may have an idiosyncratic meaning;

c. like a number of derived words, some plural nouns lack a base (the pluralia tantum).

The second and third property illustrate the tendency of inherent inflection being more susceptible to lexicalization.

As to the first property, Sassen (1992) presented a classification of such nouns for Dutch:

(1) mass nouns: wol 'wool', hooi 'hay', water 'id.', drop 'liquorice', bloed 'blood';

collective nouns: kroost 'offspring', vee 'cattle', rommel 'rubbish';

abstract nouns: aandacht 'attention', arbeid 'labour', bedrog 'deceit', geluk 'happiness';

languages: Nederlands 'Dutch', Latijn 'Latin';

diseases: griep 'influenza', bronchitis 'id.', koorts 'fever';

event names: val 'fall', gepraat 'talking', verraad 'treason';

other nouns: pech 'bad luck', publiek 'public', chaos 'id.', bluf 'boasting'.

Clearly, the lack of plural forms here is a matter of semantics: such nouns do not lend themselves to the interpretation 'more than once instance of'. This underlines the point that pluralization, as a case of inherent inflection, involves semantic change. Note also that when we pluralize such nouns, we get the concomitant semantic change 'instance of' or 'type of':

(2) bier-en 'types of beer'

kaz-en 'types/instances of cheese'

tijd-en 'times, periods'

groent-en 'types of vegetables' 
A nice example from English is the plural form Englishes that denotes the different varieties of English spoken around the world.

Examples of Dutch plural nouns with a partially unpredictable meaning are:

(3) singular:

letter 'id.'

vader 'father'

middel 'means'

zenuw 'nerve'

boek 'book'

groet 'greeting'

gedachte 'thought'

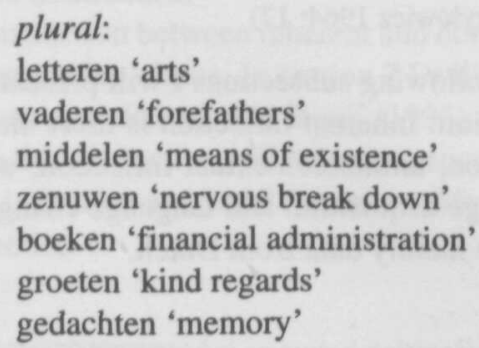

plural:

letteren 'arts'

vaderen 'forefathers'

middelen 'means of existence'

zenuwen 'nervous break down'

boeken 'financial administration'

groeten 'kind regards'

gedachten 'memory'

Dutch also features pluralia tantum (De Haas \& Trommelen 1993: 164) such as (the plural suffixes are -en and $-s$ ):

(4) Engelsen '(the) English', Fransen '(the) French', hurken 'haunches', buren 'neighbours, personalia 'id.', lendenen 'loins', ledematen 'members', ingewanden 'intestines', notulen 'minutes', Ardennen 'Ardennes', Vogezen 'Vosges', financiën ''finance', annalen 'annals', capriolen 'caprioles', inkomsten 'income', lotgevallen 'adventures', manschappen 'men', onkosten 'expenses', hoofdbrekens 'thinking', omstanders 'bystanders', waterlanders 'tears', lauweren 'laurels', lieden 'people', conserven 'canned food'

Thus, pluralia tantum form another case of lexicalization in the realm of inflection.

Dutch participles, both present and past ones, are also similar to word formation in that they may have idiosyncratic meanings, and sometimes lack a base, that is, they are also strongly subject to lexicalization:

(5) present participles: woedend 'angry' razend 'very angry' ontzettend 'very'

(6) past participles: bedonderd 'mad' belazerd 'mad' beroerd 'not well' gesloten 'close-mouthed' gezond 'healthy' gedrukt 'depressed' gedrongen 'crammed' geëerd 'venerable' gehakt 'minced meat' gehard 'tough' gehecht 'attached' base verb:

woeden 'to storm' razen 'to rage' ontzetten 'to appal'

\section{base verb:}

bedonderen 'to cheat' belazeren 'to cheat' roeren 'to stir' sluiten 'to close' zonnen 'to sun-bathe' drukken 'to press' dringen 'to push' eren 'to honour' hakken 'to cut' harden 'to harden' hechten 'to attach' 
gehouden 'obliged to' geknikt 'broken'

geknipt 'fit for' geliefkoosd 'favourite' gezocht 'popular'

\author{
houden 'to keep' \\ knikken 'to crack' \\ knippen 'to cut' \\ liefkozen 'to caress' \\ zoeken 'to look for'
}

(7) past participles without a base verb: geboren 'born', bejaard 'aged', behuisd 'lodged', bewust 'conscious', verknocht 'attached', geliefd 'beloved, favourite', vermaard 'famous', gedeisd 'calm', gehavend 'battered', gehaaid 'smart', geroutineerd 'experienced', gefortuneerd 'well off', gedecideerd 'resolute', gelardeerd 'larded', gedesillusioneerd 'desillusioned', gelinieerd 'lined'

Participles have both verbal and adjectival properties: they have the same types of dependent elements as verbs, but their distribution is that of adjectives. This makes clear that participles are not prototypically inflectional since the traditional assumption is that inflection does not change the syntactic category of its input words. ${ }^{3}$ In the case of infinitives we also get hybrid forms which retain their verbal possibilities with respect to cooccurrence with verbal arguments, but exhibit nominal properties as well. Dutch infinitives, for example, can be preceded by determiners, een ' $a$ ' and het 'the'. That is why Haspelmath (this volume) qualifies participles and infinitives as cases of category-changing inflection. They may also have idiosyncratic meanings (see the examples in (8)), and they feed denominal derivation and nominal compounding, as illustrated below in (13-14):

(8) et-en 'food', drink-en 'drinks', bestaa-n 'existence', lev-en 'life'

Other categories traditionally considered to be inflectional are the comparative and the superlative degree of adjectives. Again, as shown in Booij (1994), they are like derivation in that they may be semantically idiosyncratic, may lack a base form, and can feed both derivation and compounding. Moreover, as was the case for plural noun formation, many adjectives do not have these grade forms. This applies to all relational adjectives, to adjectives with an absolute meaning, and to adjectives with an intensifying prefix, as again illustrated by Dutch:

\section{(9) relational adjectives}

presidentieel 'presidential', *presidentieler, *presidentieelst

parlementair 'parlementary', *parlementairder, *parlementairst

absolute adjectives:

overleden 'died', *overledener, *overledenst

veroordeeld 'sentenced', *veroordeelder, *veroordeeldst

adjectives with intensifying prefixes:

doodmoe 'very tired', *doodmoeër, *doodmoest

aartslelijk 'very ugly', *aartslelijker, *aartslelijkst 
In sum, these data clearly show the similarities between derivation and inherent inflection, which induced linguists such as Kuryłowicz (1964: 37), Beard (1982), Bybee (1985), Allen (1989), Dressler (1989), Dressler \& Doleschal (1990), and Haspelmath (this volume) to consider inflection - derivation as a continuum rather than two sharply demarcated categories. It also raises the question why we do not consider inherent inflection as a subcategory of derivation. I will come back to this issue below.

\subsection{Inherent inflection feeds word formation}

As argued in Booij (1994), certain types of inflection can feed compounding and derivation. The correct generalization appears to be that it is inherent inflection that can feed word formation. Therefore, the 'split morphology' hypothesis is incorrect. ${ }^{4}$

For instance, plural nouns in Dutch form inputs for composition and derivation:

(10) composition:

[dak-en]zee 'sea of roofs'

[huiz-en]rij 'row of houses'

[held-en]verering 'heroes celebration'

[sted-en]raad 'cities council'

[mann-en]vereniging 'men's society'

[student-en]team 'students' team'

[journalist-en]forum 'journalists' panel'

[docent-en]kamer 'teachers' room'

[component-en]analyse 'components' analysis'

derivation:

[held-en]-dom 'heroism'

[ploert-en]-dom 'crooks'

[boek-en]-achtig 'like books'

[sted-en]-achtig 'like cities'

We should notice here that it is regular inflection that feeds compounding here (except for the form steden (from stad 'city') with irregular vowel change: the regular plural suffix for monosyllabic nouns and for nouns ending in a stressed syllable is -en). We cannot interpret the element -en here as a linking morpheme, or as a case of stem allomorphy: the heads of the compounds given here have a collective meaning, and therefore require a plural non-head. We also find minimal pairs such as the following, which underline the plural nature of -en:

(11) stadsraad 'city council' bedrijfswagen 'company car' volksbond 'national league' stedenraad 'cities' council'

bedrijv-enterrein 'industrial area' volk-en-bond 'League of Nations' 
These properties are by no means a unique property of Dutch. Similar facts obtain for Afrikaans (Combrink 1990) - which might be rather unsurprising since Afrikaans is historically related to Dutch. Italian and Spanish also allow plural nouns to feed word formation, as in:

(12) Italian: lavapiatti 'dish washer', portalettere 'post man', rompiscatole 'brain twister', apribottiglie 'bottle opener'

Spanish: tocadiscos 'record player', limpiabotas 'bootblack'

These facts also suggest that there cannot be an innate constraint on regular inflection feeding compounding, as suggested by Gordon (1985).

Participles also illustrate the point that inherent inflection feeds word formation, since in many languages they can be used as adjectives, and thus feed deadjectival word formation processes. For instance, Dutch past participles can be both prefixed and suffixed:

(13) on-gezocht 'not looked for' on-begrensd 'unbounded' on-verwacht 'unexpected' on-gestuurd 'undirected' on-doordacht 'thoughtless'

\author{
gezocht-heid 'artificialness' \\ begrensd-heid 'boundedness' \\ verwacht-heid 'expectedness' \\ gestuurd-heid 'directedness' \\ doordacht-heid 'well thought-outness'
}

Dutch infinitives, which have both verbal and nominal properties, can also feed both derivation and compounding:

(14) derivation with denominal -schap: wet-en-schap 'science', zegg-en-schap 'authority', wedd-en-schap 'bet', nalat-en-schap 'heritage';

non-head position of compounds: lijd-en-s-verhaal 'Passion', slap-en-s-tijd 'bed time', sterv-en-s-begeleiding 'terminal care';

head position of compounds: school-zwemm-en 'school swimming', boekbind-en 'book binding', hout-hakk-en 'wood chopping', touw-trekk-en 'rope pulling'.

The last set of examples, compounds with infinitival heads, is of particular importance. As in all Germanic languages, the process of verbal compounding is not productive in Dutch. However, the category of compounds with infinitival heads is productive, since infinitives also have nominal properties, and hence they join the productive category of nominal compounds. This implies that a word like schoolzwemmen 'school swimmming' is not the infinitive of a verbal compound, but a compound with an infinitival head. Thus, it is correctly predicted that such words do not have finite forms (Booij 1989): sentences like the following are ungrammatical:

(15) *Mijn dochter schoolzwemt 'My daughter school-swims' *Mijn buurman boekbindt 'My neighbour book-binds' 
Instead, a periphrastic construction has to be used:

(16) Mijn dochter is aan het schoolzwemmen 'My daughter is doing school swimming'

Mijn buurman is aan het boekbinden 'My neighbour is doing book-binding'

Yet, even in these compound forms such infinitives retain verbal properties. For instance, like simplex infinitives, and unlike pure nouns, they combine with auxiliaries:

(17) Ik ga morgen schoolzwemmen

'Tomorrow, I am going to schoolswim'

In sum, there are many cases of what is traditionally called inflection that are similar to derivation. This suggests that this kind of inflection has to be accounted for by the same kind of morphological rules that account for derivation, i.e. morphological rules in the lexicon, which function both as redundancy rules and as creative rules. Thus, it also follows that these morphological processes can feed (further) word formation, since lexical rules may feed other rules. Therefore, this kind of inflection, which we have called inherent inflection, cannot be relegated to a post-syntactic component of morphological spell-out rules.

It is only inherent inflection that may feed word formation. The fact that contextual inflection does not do so, can be assumed to follow from its nature: contextual inflection must be visible on the top node of its word, because otherwise it is invisible for the syntactic context. Therefore, it must be able to add its morphosyntactic features to the top node of the word to which it belongs. This is impossible if inflection precedes derivation, because a derivational suffix adds.its own 'categorial signature' (Lieber 1989) to a complex word, and will block percolation of the inflectional features to the top node:

(18)

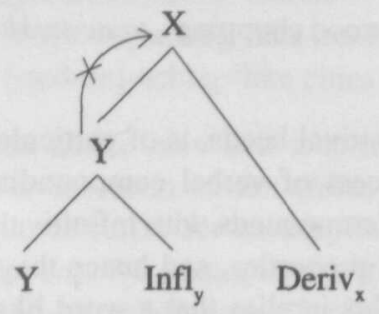

In the case of inherent inflection this is no problem. For instance, the plural property of a noun need not percolate upwards, since its function is primarily semantic (although it may have syntactic relevance for agreement). Therefore, we do find plural nouns in the non-head position of compounds and certain types of derived words. The same holds for verbal infinitives: the suffix functions as a nominalizer, and it is this nominalized form that functions as input for compounding and denominal word formation. ${ }^{5}$ 
It should be pointed out here that we do find contextual inflection inside words, but only when the inflected word forms part of a phrase that is embedded in a word. For instance, Dutch allows for phrasal non-heads in compounds, as in

(19) [[oude mannen $\left.]_{\mathrm{NP}}[\text { huis }]_{\mathrm{N}}\right]_{\mathrm{N}}$ 'old men's home' $\left[[\text { kleine boeren }]_{\mathrm{NP}}[\text { bond }]_{\mathrm{N}}\right]_{\mathrm{N}}$ 'small farmers' union'

The italicized $e$ 's in these examples are cases of contextual inflection. The presence of this contextual inflection is necessary because the adjective is used here attributively in a phrase. Therefore, these are not cases in which contextual inflection feeds word formation in a direct way. ${ }^{6}$

Although we have to allow for inherent inflection to feed word formation, that does not mean that there are no restrictions on this type of interaction. Whereas plural nouns and infinitives can form inputs for compounding, this does not apply to all kinds of derivation: derivational suffixes mostly attach to the stems of words, i.e. the forms stripped from all their inflectional suffixes. For instance, deverbal -ernouns and denominal -ig-adjectives have the following forms:

(20)
a. infinitive
stem
noun
kop-en 'to buy' koop
kop-er (*kop-en-er) 'buyer'
fiets-en 'to cycle'
fiets
b. noun
plural
fiets-er (*fiets-en-er) 'cyclist'
haar 'hair'
har-en
adjective
kat 'cat'
katt-en
har-ig (*har-en-ig) 'hairy'
katt-ig, (*katt-en-ig) 'catty'

On the other hand, the derivational suffixes that form prosodic words of their own, such as -achtig, -dom and -schap, can be attached to inherently inflected bases:

(21) helden-achtig 'heroes-like', boeken-achtig 'books-like', helden-dom 'heroism', ploerten-dom 'set of crooks', leerlingen-dom 'set of pupils', wetenschap 'science', wedden-schap 'bet', zeggen-schap 'authority'

These suffixes derive historically from lexemes.

That infinitives do not feed deverbal word formation follows from the categorial status of the infinitives: they are no longer pure verbs, and behave as nouns in word formation. Note also that the suffix -schap mentioned in the examples in (21) is a denominal suffix, which explains why it can take infinitives as bases. On the other hand, the deverbal suffix -baar '-able' cannot be attached to infinitival forms which again suggests that the infinitive behaves as a noun in word formation. Similarly, verbal participles do not function as verbal bases, but as adjectival bases in word formation. ${ }^{7}$

The generalization with respect to the nominal plural suffix seems to be that it can only occur at the right edge of a prosodic word. Therefore, it cannot be followed by cohering suffixes, i.e. suffixes that do not form prosodic words on their own, such as -ig and -er. Note that -dom is a non-cohering suffix. So the plural suffix functions as a closing morpheme in the prosodic sense of 'closing', since derivational suffixes 
that begin a new prosodic word are not affected by this constraint. ${ }^{8}$ This supports the claim that morphological constraints must be able to refer to prosodic properties (Booij \& Lieber 1993).

It should be realized that the use of inflected words as bases for compounding and derivation has a rather marked character. The use of a plural nominal form in the non-head position of compounds is semantically adequate in case the head is a collective noun. Note that a noun in its non-plural form is not to be interpreted as a singular noun. Rather, it is a nominal stem that is not specified for its number, and this will do. For instance, in the compound bookseller the left constituent book is not to be interpreted as a singular noun. Instead, it has a categorial interpretation, and refers to the category of books. The same remark applies to the use of comparative forms of adjectives. In a verb like vergeel (derived from the adjective geel 'yellow') with the meaning 'to become yellow', there is no need to use a comparative form geler since the meaning of ver-verbs is that the object gets the property indicated by the adjective to a larger degree.

What about the word-internal use of nominal case? Traditionally, a distinction is made between structural case and semantic case. ${ }^{9}$ In Hungarian, for instance, nominative and accusative are structural cases (i.e. contextual inflection), whereas there is also a number of semantic cases, such as the inessive ('in') that functions as inherent inflection. As predicted by our hypothesis that it is only inherent inflection that feeds word formation, semantic cases do occur inside Hungarian complex words, unlike structural cases. Consider the following data from Kiefer (1990):

(22) a. újsag-olvas-ás 'newspaper reading'

levél-ír-ás 'letter writing'

b. újsag-olvas- 6 'newspaper reader' levél-ír-o 'letter writer'

(23) a. iskolá-ba-jár-ás school-ILLATIVE-go-NOM 'going to school, school attendance'

b. férj-hez-men-és husband-ALLATIVE-go-NOM 'getting married'

c. hely-ben-lak-ás place-INESSIVE-live-NOM 'living in the same locality, inhabitancy'

In the examples (22) the words ujság and levél are not case-marked by the structural accusative case, whereas in (23) semantic case (inherent inflection) is used wordinternally. Similar observations concerning the word-internal occurrence of semantic case can be found in Booij (1994: 42-43) for Warlpiri, Warumungu, and Eskimo. With respect to Eskimo, this point was also made by Allen (1988). In her discussion of noun incorporation in Eskimo, she pointed out that structural cases (nominative, accusative, absolutive, ergative) do not appear inside compounds created by noun incorporation, whereas semantic cases such as allative, locative, ablative, translative, and simulative do appear within such verbal compounds. 
According to Allen, these facts speak against a lexicalist analysis of this type of word formation, because such an analysis would make us expect that all types of cases can appear within such verbal compounds. She decides to take a Bakerian syntactic incorporation analysis (cf. Baker 1988): semantic cases are cases assigned at D-structure - and hence they can be incorporated -, and structural cases are assigned at S-structure, after the possible application of the syntactic rule of incorporation, and hence there is way of deriving compounds with word-internal structural case. However, a lexicalist approach is also feasible. We then account for this constraint on the interaction of inflection and word formation as follows: syntactic case makes only sense if it can percolate to the whole word, and thus be visible for the word-external syntactic context. In more formal terms: morphosyntactic features for structural case must be licensed by the syntax, and this is only possible when they are visible to syntax, that is, are features of the top node of the word structure. Semantic case, on the other hand, has its own meaning contribution to the complex word, needs no syntactic licensing, and can thus appear in the non-head position of complex words.

\subsection{Affix order}

As pointed out in Booij (1994: 35), the following generalization with respect to the order of inflectional morphemes can be made: contextual inflection tends to be peripheral with respect to inherent inflection. For instance, case is usually external to number, and person and number affixes on verbs are external to tense and aspect morphemes. This tendency is also observable in the phenomenon of externalization of inflection discussed by Haspelmath (1993): when a case suffix gets stuck inside a noun, or person/number markers inside a verb, due to the grammaticalization of clitic-like elements, these markers of contextual inflection tend to externalize. Clearly, it is in particular contextual inflection that tends to externalize in such circumstances. $^{10}$

To be sure, this affix order constraint should not be seen as an absolute constraint. For instance, Blake (1994: 106) mentions Classical Armenian as a language in which -exceptionally!- the morphological expression of Number is peripheral to that of Case. Nevertheless, it is clear that the inherent-contextual distinction is indispensable for stating tendencies in affix order.

\subsection{Language acquisition}

Although it is not true that the acquisition of all inherent inflection precedes that of all contextual inflection, there is evidence that inherent inflection has a certain priority over contextual inflection in language acquisition. For instance, in the acquisition of the inflectional morphology of Dutch, the acquisition of plural nouns takes place much earlier than that of the finite forms of verbs (Schaerlaeckens \& Gillis 1987). For quite some time, Dutch children use the infinitive form as a general form 
of the verb in subject-verb combinations, at a stage where plural forms of noun are already used properly. This is to be expected since it is inherent inflection that has its own semantic contribution to a sentence, whereas the person/number suffix in a verbal form does not express independent information. De Villiers \& De Villiers (1986: 68) reported the following order of acquisition of grammatical morphemes in English:

(24) Present Progressive

Plural

Past Irregular

Possessive

Past Regular

Third Pers. Singular

Third Pers. Irregular

It is only the last two categories that are contextual inflection. This suggests that the inherent - contextual distinction is relevant for the order of acquisition of grammatical morphemes. ${ }^{11}$ Slobin (1986: 10) also points out that aspectual distinctions expressed by verbs are acquired at an early age, and before person marking is mastered.

Clahsen's study of the language development of German-speaking languageimpaired children also supports the distinction advocated here. Clahsen (1989) observed that with respect to the acquisition of inflectional morphology such children only have problems with subject-verb-agreement, case, and article-noun agreement. That is, it is typically contextual inflection that poses a problem for them. In Clahsen \& Rothweiler (1992), it has been reported that such children do not have problems in acquiring German (past) participles.

The priority of inherent inflection above contextual inflection in the process of language acquisition can also be observed in the acquisition of inflected verbal forms in German. Clahsen (1986) found that, initially, the person/number suffixes, typical cases of contextual inflection, do not express subject-verb agreement; instead, these suffixes encode semantic functions, in particular the difference between semantically transitive and semantically intransitive verbs: the suffix $-t$ appeared to encode that the subject is a non-agent, whereas the use of $-n,-e$, or $-\varnothing$ meant that the subject is an agent.

\section{IS INHERENT INFLECTION PART OF DERIVATION?}

Given the similarities between derivation and inherent inflection, we might consider subsuming inherent inflection under derivation, and reserving the term inflection for contextual inflection.

An argument for keeping the distinction between inherent inflection and derivation comes from Chelliah (1992) who observed the following for the Tibeto-Burman language Manipuri. In this language all inflection is inherent in that it has no syntactic consequences. Yet, the structure of a complex word is 


\section{(25) Root - Derivation - Inflection}

where both derivational and inflectional suffixes are optional. The reason for keeping the distinction is that this makes it possible to express the following: in the realm of the derivational suffixes, the morpheme order is variable, with concomitant meaning differences, whereas the inflectional morphemes have to appear in a fixed order. So this distinction is useful for making generalizations about affix order. Also, derivational affixes may occur twice, unlike inflectional affixes.

However, this does not mean that we can relegate inherent inflection to the derivational component. The point is that the same suffix can be used for both inherent and contextual inflection. For instance, many suffixes that express structural case, can also be used for semantic case (Kuryłowicz 1964: 179, Luraghi 1991, Blake 1994).

Another consideration is that in fusional languages one inflectional affix may express both inherent and contextual categories. For instance, in Latin nouns there is one ending for number and case. Thus, it is impossible to account for the morphological expression of number in another component than that for case.

Erasing the distinction between derivation and inherent inflection also has the undesirable consequence that the notion 'stem' (word minus both inherent and contextual inflectional elements) is no longer properly definable. Yet, it is often the stem that is the form in which a lexeme forms the basis of word formation.

Note also that in some languages contextual and inherent inflection form a block in the phonological sense, and then stand in opposition to derivation. For instance, in Brazilian Portuguese, derivational processes trigger the application of phonological rules concerning mid vowel alternations (Wetzels, 1995), unlike inflectional processes. That is, phonology still requires inherent and contextual inflection to be treated as distinct from derivation.

\section{CONCLUSIONS}

In this paper we have seen that inflection and derivation cannot be considered to be two completely separate components of the grammar. Inherent inflection appeared to share a number of properties with derivation, implying a lexical account of such types of inflection. Moreover, inherent inflection can feed derivation and compounding, as was shown in Booij (1994), and in this paper. Thus, inflection must be allowed to interact with word formation, contrary to the predictions of the hypothesis of split morphology. This leads to the conclusion that either 'strong lexicalism' is the correct view of the position of morphology in the grammar, or that all morphology must be done in syntax. I take it as well established that the latter position is untenable.

Although inflection and derivation have to be located in one component, it does not mean that there are no restrictions on their interaction. We saw that it is only inherent inflection that feeds word formation. This follows from the idea that such 
inflectional features need not be licensed by syntax, and hence can occur wordinternally, without being visible to syntactic principles of licensing. The distinction between inherent and contextual inflection was also supported by data concerning language acquisition and language change.

We also concluded that inherent inflection, although it is similar to derivation in certain respects, should not be identified with derivation. It is halfway on a scale with at one end contextual inflection (the prototypical case of inflection), and at its other end derivation.

\section{NOTES}

1 This paper is the revised form of a talk given at the 6th International Morphology Meeting, Szombathely, Hungary, 16-18 September 1994. I would like to thank the audience in Szombathely, Martin Haspelmath, and Andrew Spencer for their useful comments.

2 The interest in these topics is also clear from the fact that at the 1992 Berkeley Linguistics Conference a special parasession was devoted to the topic 'The place of morphology in grammar' (see Proceedings of the Berkely Linguistic Society 19 (1992)).

3 A detailed analysis of this ambiguous behaviour of participles in Biblical Hebrew can be found in Dyk (1994).

4 Diachronic arguments against the split morphology hypothesis can be found in Chapman (1994).

5 As pointed out in Booij (1994), the fact that tense, a case of inherent inflection, does not appear in the non-head position of compounds, may be assumed to follow from its deictic nature: deictic expressions cannot occur in the non-head position.

6 The fact that phrases are allowed in the non-head position of compounds could also be used to explain the occurrence of plural nouns in that position. For instance, one might consider huizen in huizenrij 'row of houses' as a phrase consisting of a plural noun only. In such an analysis the occurrence of word-internal plural suffixes follows from phrasal inputs being allowed for compounding. However, some of the suffixes that allow for plural nouns as their bases do not allow for phrasal bases. In particular, this applies to the collective suffix -dom: we cannot form a word such as [[grote helden $]_{\mathrm{NP}}$ dom $]_{\mathrm{N}}$ 'big heroism'. That is, in these cases a phrasal explanation of word-internal plural nouns appears to be inadequate.

1 There are a few verbs which have the infinitival schwa-less suffix $-n$, and seem to allow for deverbal derivation from the infinitive. The verbs concerned are doen 'to do', gaan 'to go', slaan to beat', staan 'to stand', and zien 'to see'. The following examples illustrate their derivational possibilities:

(1) doen-er 'doer', af-doen-de 'sufficient', on-doen-lijk 'impossible'

be-gaan-baar 'passable', uit-gaan-der 'out-goer', gaan-derij 'gallery';

slaan-d 'beating';

staan-der 'stand', staan-d 'standing';

zien-er 'prophet', onaf-zien-baar 'endless', on-zien-lijk 'invisible', voor-zien-ing 'provision', voor-zien-ig 'providential', aan-zien-lijk 'considerable'

However, it is questionable whether the relevant inputs are really infinitives, given our observation that infinitives function as nominal bases in word formation. Therefore, we should interpret forms like doen /dun/ as a second stem for the lexeme DOE 'to do', which is to be used in suffixation, in the spirit of Aronoff (1994). See Booij (ms.) for a more detailed analysis of such facts.

8 However, the $/ \mathrm{s} /$ that functions as a linking phoneme can follow -en as in lijden-s-tijd 'passion time'. Note that $/ \mathrm{s} /$ at the end of a prosodic word has a special status in Dutch, that of appendix (Booij 1995). 
9 See for instance Kuryłowicz (1964) and Blake (1994: 32-34).

10 This was pointed out to me by Franz Rainer.

1 Spencer (pers. comm.) suggested an alternative explanation for the relatively late acquisition of the 3rd pers. s.g forms: the morphological expression of the 3rd pers. sg. in English has a marked character since it is not expressed by zero.

\section{REFERENCES}

Allen, S. 1988. "Noun Incorporation in Eskimo: Postpositions and Case Marking". Mc Gill Working Papers in Linguistics 5 (2), 1-39.

Allen, A. S. 1989. "The Lexical, Derivational, and Inflectional Continuum in Verb Morphology". In Th. Walsh (ed.) GURT '88. Synchronic and Diachronic Approaches to Linguistic Variation and Change. Georgetown: Georgetown University Press, 1-7.

Anderson, S. R. 1992. A-morphous Morphology. Cambridge: Cambridge University Press.

Aronoff. M. 1994. Morphology by Itself. Cambridge MA: MIT Press.

Baker, M. 1988. Incorporation. Chicago: Chicago University Press.

Beard, R. 1982. "The Plural as a Lexical Derivation". Glossa 16, 133-148.

Blake, B. 1994. Case. Cambridge: Cambridge University Press.

Booij, G. E. 1989. "Complex Verbs and the Theory of Level Ordering". In G. E. Booij \& J. van Marle (eds.) Yearbook of Morphology 1989. Dordrecht: Foris, 21-30.

Booij, G. E. 1994. “Against Split Morphology”. In G. E. Booij \& J. van Marle (eds.) Yearbook of Morphology 1993. Dordrecht: Kluwer, 27-50.

Booij, G. E. 1995. The Phonology of Dutch. Oxford: Clarendon Press.

Booij, G. E. ms. "Autonomous Morphology". HIL / Vrije Universiteit Amsterdam.

Booij, G. E. \& R. Lieber 1993. "On the Simultaneity of Morphological and Prosodic Structure". In S. Hargus \& E. Kaisse (eds.) Studies in Lexical Phonology. San Diego: Academic Press, 23-44.

Bybee, J. 1985. Morphology. Amsterdam: John Benjamins.

Chapman, C. 1994. "A Diachronic Argument against the Split Morphology Hypothesis". Transactions of the Philological Society 92, 25-39.

Chelliah, S. 1992. "Pretty Derivational Morphemes All in a Row". Proceedings of the Berkely Linguistic Society 18, 287-297.

Clahsen, H. 1986. "Verb Inflection in German Child Language: Acquisition of Agreement Markings and the Functions they Encode". Linguistics 24, 79-121.

Clahsen, H. 1989. "The Grammatical Characterization of Developmental Dysphasia". Linguistics 27, 897-920.

Clahsen, H. \& M. Rothweiler 1992. "Inflectional Rules in Children's Grammars: Evidence from German Participles". In G. E. Booij \& J. van Marle (eds.) Yearbook of Morphology 1992. Dordrecht: Kluwer, 1-34.

Combrink, J. G. H. 1990. Afrikaanse Morfologie. Pretoria: Academica.

Dressler. W. U. 1989. "Prototypical Differences between Inflection and Derivation". Zeitschrift für Phonetik, Sprachwissenschaft und Kommunikationsforschung 42, 3-10.

Dressler, W. U. \& U. Doleschal 1990. "Gender Agreement via Derivational Morphology". Acta Linguistica Hungarica 40, 115-137.

Dyk, J. 1994. Participles in Context. A Computer-assisted Study of Old Testament Hebrew. Amsterdam: VU University Press.

Gordon, P. 1985. "Level Ordering in Lexical Development". Cognition 21, 73-93.

Groot, A. W. de 1966. "Structurele verschillen tussen flexie en derivatie". In Id., Betekenis en betekenisstructuur. Groningen: Wolters-Noordhoff, 75-100.

Haas, W. de \& M. Trommelen 1993. Morfologisch handboek van het Nederlands. 's-Gravenhage: SDU Uitgeverij. 
Haspelmath, M. 1993. "The Diachronic Externalization of Inflection". Linguistics 31, 279310.

Haspelmath, M. 1994. "Word-class Changing Inflection and Morphological Theory". This volume.

Imidadze, N. \& K. Tuite 1992. "The Acquisition of Georgian". in Slobin (ed.), 39-109.

Kiefer, F. 1990. "Noun Incorporation in Hungarian". Acta Linguistica Hungarica 40, 149178.

Kuryłowicz, J. 1964. Inflectional Categories of Indo-European. Heidelberg: Carl Winter.

Lieber, R. 1989. "On Percolation”. In G. E. Booij \& J. van Marle (eds.) Yearbook of Morphology 1989. Dordrecht: Foris, 95-138.

Luraghi, S. 1991. "Paradigm Size, Possible Syncretism, and the Use of Adpositions with Cases in Flective Languages." In F. Plank (ed.) Paradigms. The Economy of Inflection. Berlin/New York: Mouton de Gruyter, 57-74.

Perlmutter, D. M. 1988. "The Split Morphology Hypothesis, Evidence from Yiddish". In M. Hammond \& M. Noonan (eds.) Theoretical Morphology. San Diego: Academic Press, 79 100.

Sassen, A. 1992. "Meervoudloosheid en indeling van Nederlandse zelfstandige naamwoorden". In H. Bennis \& J. W. de Vries (eds.) De Binnenbouw van het Nederlands. Dordrecht: ICG Publications, 329-341.

Schaerlaeckens, A. M. \& S. Gillis 1987. De taalverwerving van het kind. Groningen: WoltersNoordhoff.

Schultink, H. 1962. De morfologische valentie van het ongelede adjectief in modern Nederlands. Den Haag: Van Goor Zonen.

Slobin, D. I. (ed.) 1986-1992. The Cross-linguistic Study of Language Acquisition. 3 Vols. Hillsdale N.J.: Lawrence Erlbaum Associates.

Villiers, J. G. de \& P. A. de Villiers 1986. "The Acquisition of English". In Slobin (ed.), Vol I, 27-139.

Wetzels, L. 1995. "Mid-vowel Alternations in the Brazilian-Portuguese Verbs". Phonology $12,281-304$.

\author{
Holland Institute of generative Linguistics \\ Vrije Universiteit, Vakgroep Taalkunde \\ De Boelelaan 1105 \\ $1081 \mathrm{HV}$ Amsterdam \\ The Netherlands \\ e-mail: booij@let.vu.nl
}

